\title{
Visual versus mechanised leucocyte differential counts: costing and evaluation of traditional and Hemalog D methods
}

\author{
MJ HUDSON AND AE GREEN
}

From the Haematology Departments, St Mary's Hospital and Queen Alexandra Hospital, Portsmouth, UK

SUMMARY Visual differential counts were examined for efficiency, cost effectiveness, and staff acceptability within our laboratory. A comparison with the Hemalog $D$ system was attempted. The advantages and disadvantages of each system are enumerated and discussed in the context of a large general hospital.

The Technicon Hemalog $\mathrm{D}$ has been described and demonstrated extensively, ${ }^{1-3}$ as has the precision and accuracy of the traditional method of differential white cell counting. ${ }^{2} 4$ The staff of many large haematology laboratories will be faced with the decision whether or not to plan to include a system such as the Hemalog D in their attempts to keep pace with the apparently ever increasing flow of work. We have attempted to answer some basic questions.

\section{Analysis of traditional blood film examination}

As we wished to assess the amount of use that would be made of a Hemalog $\mathrm{D}$ it became obvious that we needed a clear idea of the number of blood films that are examined in our present system of work. These data were not readily available and so, while collecting them, we decided to extend the survey to attempt to define what type of film examinations were being made, how many hours were spent doing this, and the reactions of staff to this aspect of their work.

A questionnaire was devised to be completed for one week anonymously by each of 13 members of staff qualified to examine films (Table 1).

The results for the week studied are shown in Table 2.

There was little daily variation in the percentage or the staff reaction. The variation that did occur reflects the hospital routine whereby the type of outpatient clinic varies daily. The main variation found was in the number of staff available for film examination each day which reflected illness and 'day release' for educational purposes and ranged

Received for publication 25 March 1980
Table 1 Questionnaire to be completed by staff

How many films have you looked at today?

To the nearest half hour how long did this take?

How many differential counts have you done?

How many abnormalities OTHER THAN change in differentia count, $\mathrm{MCH}$, and $\mathrm{MCV}$ did you find?

How many times did the film appearance lead to checking the countin machine results?

At the end of each day I felt about looking at films-happy/conten neutral/bored/fed up.

\section{Table 2 Results of questionnaire}

\begin{tabular}{lrl}
\hline Total specimens for blood counts: & 2567 & \\
Total films examined: & 1423 & $55 \%$ of specimens \\
Total differential counts: & 472 & $33 \%$ of specimens \\
Other abnormalities found (see & & \\
$\quad$ text): & 289 & $20 \%$ of films examined \\
Film examination leading to & 9 & \\
$\quad$ counting machine check: & 5 & \\
I felt happy: & 8 & \\
$\quad$ content: & 27 & \\
$\quad$ neutral: & 2 & \\
$\quad$ bored: & 2 & \\
$\quad$ fed up: & 44 & \\
Number of staff/days involved: & 67 hours $11.5 \%$ of working \\
Time spent: & 32 & week \\
Films per member of staff: & 21 & \\
Films per hour worked: &
\end{tabular}

between 6 and 12 . Thus the number of films examined per member of staff varied between 19 and 45 . However, it is interesting that the rate of film examination was remarkably constant at between 19 and 22 films per hour.

In summary, just over half the specimens received for a blood count had a film examined, and, of these, one-third required a formal differential count. Over one-fifth of the films examined had abnormalities other than those which would be quantitated by a Coulter $\mathrm{S}$ or Hemalog $\mathrm{D}$ printout. 
A small but important number of film examinations led to a check of the Coulter $S$ printout.

Most members of staff at the end of the day felt 'neutral' about the job, but there was a distinct tendency to feel satisfied rather than dissatisfied by it.

Film examination accounted for some $11 \%$ of the working week, and individuals spent between 1 and 2 hours a day on this aspect of the department's work. However, only two of the 13 members of staff qualified to do this work looked at films every day of the week studied.

Taking a median point on the Medical Laboratory Scientific Officer (MLSO) salary scale, film examination cost $£ 128.71$ in staff time during the week and an additional $£ 22.41$ on materials. Allowing 15 years as the life of a microscope, an additional $£ 13.00$ may be added per week for capital depreciation of all microscopes and a further $£ 2.00$ for staining machine capital depreciation. The cost per week of film screening is therefore $£ 166.12$ or $12 p$ per film.

\section{Hemalog D evaluation}

In our study, we considered four aspects of the instrument's performance: its use as a screening instrument, its precision in routine use, the information it produces in leucocyte abnormalities, and the running costs.

\section{USE AS A SCREENING INSTRUMENT}

All blood samples received in our department have a film examined unless they are from $(a)$ postnatal women with haemoglobins higher than $9 \mathrm{~g} / \mathrm{dl}$, white cell counts below $20000 \times 10^{9} / 1$, and a normal $\mathrm{MCH}$ and MCV; (b) antenatal women with haemoglobins above $10 \mathrm{~g} / \mathrm{dl}$, white cell counts between 4000 and $15000 \times 10^{9} / 1$, and a normal $\mathrm{MCH}$ and $\mathrm{MCV}$; (c) postoperative patients with haemoglobins above $9 \mathrm{~g} / \mathrm{dl}$, white cell counts below $15000 \times 10^{9} / 1$, and a normal $\mathrm{MCH}$ and $\mathrm{MCV}$; or $(d)$ preoperative patients with a strictly normal Coulter $S$ profile and a diagnosis considered not to necessitate a film examination.

During the test week a representative sample of these cases was processed by the instrument. Only one abnormality was detected: a peroxidase deficiency in an otherwise healthy postnatal woman. A blood film was examined and no morphological abnormality was seen.

\section{IMPACT OF PRECISION}

As the considerably greater precision of the Hemalog 30000 cell differential over 100 cell visual differentials is well established, we did not seek to undertake a statistical comparison in our laboratory. Instead we sought to gain a general impression of the comparison of the two methods under 'routine' conditions.

It was arranged that a single sample of blood should be divided into six aliquots and sent to the laboratory labelled as six different fictitious patients, accompanied by falsely detailed request forms necessitating a differential, during the week when all differentials were being done on the Hemalog D. This exercise was also carried out with a different sample during the analysis of traditional blood film examination, and no member of the haematology department was aware that it was taking place on either occasion. We had planned to repeat this study several times during the trial, but the considerable practical difficulties encountered prevented this. The results are shown in Table 3.

Table 3 Comparison of differential cell count by the two methods

\begin{tabular}{|c|c|c|c|c|c|c|c|c|c|c|c|c|}
\hline \multirow[t]{2}{*}{ Cells } & \multicolumn{6}{|c|}{ Hemalog D } & \multicolumn{6}{|c|}{$\begin{array}{l}\text { Visual } 100 \text { cell } \\
\text { differential }\end{array}$} \\
\hline & $I$ & 2 & 3 & 4 & 5 & 6 & 1 & 2 & 3 & 4 & 5 & 6 \\
\hline Neutrophils & 58 & 58 & 60 & 60 & 59 & 57 & 25 & 29 & 30 & 36 & 42 & 44 \\
\hline Eosinophils & 1 & 1 & 1 & 1 & 1 & 1 & 5 & 4 & 6 & 7 & 2 & 5 \\
\hline Basophils & 2 & 2 & 1 & 2 & 1 & 2 & 2 & 1 & - & 4 & - & - \\
\hline Lymphocytes & 33 & 33 & 32 & 31 & 33 & 34 & 63 & 63 & 58 & 49 & 52 & 45 \\
\hline Monocytes & 6 & 6 & 6 & 6 & 6 & 6 & 5 & 3 & 6 & 4 & 4 & 6 \\
\hline
\end{tabular}

To enable a direct comparison to be made of percentage results of the two methods, when the Hemalog D printed a positive figure for the remainder (cells classified by the peroxidase channel as monocytes and basophils exceed the sum of monocyte and basophil channels) it was added to the monocyte count. Negative remainders (the sum of the monocyte and basophil channels exceed the number of cells classified as monocytes or basophils by the peroxidase channel) were subtracted from the neutrophil count. Figures in the large unstained cells (LUC) category were added to the lymphocyte count.

\section{INFORMATION IN LEUCOCYTE}

ABNORMALITIES

Many haematological conditions produce characteristic patterns of results on the Hemalog D. During the trial we studied a large number of abnormal blood samples in order to evaluate the information produced by the instrument. The series included samples with numerical abnormalities and samples with morphological abnormalities. Among the disease states studied were infectious mononucleosis and other viral infections, myelofibrosis, myeloma, and the following types of leukaemia; chronic granulocytic, chronic monocytic, chronic lymphatic, 
and acute lymphoblastic. Also included were samples from children and from patients on immunosuppression and chemotherapy.

The most important observation in this study was the instrument's ability to demonstrate slight shifts in very small subpopulations of leucocytes, which were not detected by visual differentials of 100 cells.

Within the group of lymphocytic leukaemias the instrument demonstrated (both with raised LUC counts and on oscilloscope displays) small populations of 'abnormal' lymphocytes, distinct from the main lymphocyte populations, in patients whose blood films appeared normal. Also demonstrated in one patient within this group were two large overlapping populations of lymphocytes when the blood film showed no evidence of two morphologically distinct lymphocyte populations. The Hemalog D was able to demonstrate very small subpopulations in patients with viral infections and lymphopenia.

\section{RUNNING COSTS}

Our estimate of the running costs of the Hemalog D is shown in Table 4. The estimate of depreciation costs is based on a capital cost of $£ 74000$ for the system written off over 10 years. We consider that the running of the instrument requires the full-time attendance of one basic grade MLSO and have estimated the costs in staff time accordingly. We have assumed a workload of 1423 differentials per week, the number examined in our test week for visual differentials of 100 cells.

\section{Table 4 Running costs of Hemalog D}

\begin{tabular}{lr} 
Reagents & $£ 98 \cdot 30$ \\
Printer paper & $£ 45 \cdot 23$ \\
Recorder paper & $£ 2 \cdot 16$ \\
Other consumables, eg, pump tubing, filters & $£ 17 \cdot 74$ \\
Depreciation & $£ 142 \cdot 30$ \\
Staff time & $£ 72.99$ \\
Total & $£ 378 \cdot 72$ \\
Cost per sample & $26.6 \mathrm{p}$ \\
\hline
\end{tabular}

If an annual preventive maintenance contract were purchased sample costs would rise to $34 \cdot 3 \mathrm{p}$. If all the 2567 specimens received weekly were procsssed by the Hemalog $D$ the cost per sample would be $18 p$ (or 23p if a service contract were purchased).

The saving in staff time per week resulting from the use of the Hemalog D instead of visual 100 cell differentials would be 67 hours. However, $20 \%$ of films would still have to be inspected visually for abnormalities other than the leucocytes (see above), reducing this saving to 54 hours. This represents a saving on salaries of $£ 182.90$ per week, or $13 p$ per sample. We have not shown this figure in Table 3 because we do not consider it to be a 'real' saving; staff not employed examining blood films would not be dismissed but would undertake other tasks. However, if such savings are included, on the basis that increases in staff to cope with an increasing workload could be deferred for several years, the Hemalog D cost falls to $13.6 \mathrm{p}$ per sample. This is very close to the figure obtained for the cost of visual 100 cell differentials in our laboratory.

\section{Discussion}

The main advantages of the Hemalog D stem from its ability to classify large numbers of cells very quickly. In view of this it is hardly surprising that we found the Hemalog $\mathrm{D}$ to be considerably more precise than visual 100 cell differentials in routine use. We feel that this is a strong point in its favour. We also feel that it gives a more accurate and complete picture of leucocyte population dynamics than the visual differential, particularly when the information from the oscilloscope display is added to the printed results (this facility is available at extra cost).

The ability of the instrument to detect and monitor shifts in small subpopulations of leucocytes offers several advantages. One of these is the ability to produce meaningful differentials on samples with very low total white cell counts. Another is the earlier and more reliable detection of trends in the white cell populations of patients on chemotherapeutic agents (eg, reappearance of blast cells during relapse of leukaemia). It is possible that, in the future, such monitoring of subpopulations may have important clinical implications. ${ }^{5}$

We found that the number of staff available to examine blood films varied considerably from day to day during the week studied, and also that the majority felt only neutral about this task. The Hemalog D offers considerable advantages in this area with its permanent availability and workload capacity.

The capital cost is the largest item in a cost analysis of the Hemalog $D$ and is fixed over the life of the instrument. The major cost of the visual method is staff salaries, and this will rise steadily over the same period.

In our laboratory visual differentials of 100 cells would cost approximately half as much as a differential from the Hemalog D.

The amount of useful additional information from our assessment of the instrument's screening function was minimal, the only abnormality found being a peroxidase deficiency. However, the patients in this section were a highly selected group.

We found that $20 \%$ of the blood films we examined visually in one week had abnormalities other 
than leucocyte abnormalities. Some of these were abnormalities of the platelet count and could be eliminated from the $20 \%$ mentioned above if the Hemalog D was used in conjunction with a platelet counting system. The remaining morphological abnormalities of red cells would then go undetected by the Hemalog D system.

The Hemalog $\mathbf{D}$ is unable to deal with samples whose total white cell count falls outside the range $4-20 \times 10^{9} / 1$ without dilution or alteration of instrument mode. A significant proportion of our workload falls outside this range, necessitating an extra step and adding to the cost.

We found the instrument easy to operate, after a short training session, and no breakdowns occurred during the trial period.

We are grateful to the Technicon Instruments Co Ltd for the loan of a Hemalog D for three weeks and for their help and advice during our evaluation.
References

${ }^{1}$ Mansberg HP, Saunders AM, Groner W. The Hemalog D white cell differential system.J Histochem Cytochem 1974; 22:711-24.

2 Simmons A, Elbert G. Hemalog D and manual differential leucocyte counts. Am J Clin Path 1975;64:512-7.

${ }^{3}$ Ross D, Bayer C. Evaluation of the Hemalog D Automated White Blood Cell Differential in Haematology Patients. Technicon Symposium: Frankfurt 1978.

${ }^{4}$ Winkel P, Statland BE, Harris SC, Burdsall MJ, Lintrup J, Saunders AM. A study of variation of concentration values of leucocyte types; analytical considerationsmanual $v$ automated cell counting. 7th Technicon International Congress, 1976.

${ }^{5}$ Binet JL, Vaugier G, Dighiero G, d'Athis P, Charron D. Investigation of a new parameter in chronic lymphocytic leukaemia; the percentage of large peripheral lymphocytes determined by the Hemalog D. Am J Med 1977;63:683-8.

Request for reprints to: MJ Hudson, Central Laboratory, St Mary's Hospital, Milton Road, Portsmouth, Hants, UK. 